\title{
On-Pump Beating Heart Endoventriculoplasty Using Autologous Endocardium for Left Ventricular Aneurysm Repair
}

\author{
Gürsel Levent Oktar ${ }^{1}$, Monica Gianoli², Fabiano Porta ${ }^{3}$, Jan Grandjean³ \\ ${ }^{1}$ Department of Cardiovascular Surgery, Faculty of Medicine, Gazi University, Ankara, Turkey \\ ${ }^{2}$ Department of Cardiothoracic Surgery, Catharina Ziekenhuis, Eindhoven, Netherlands \\ ${ }^{3}$ Department of Cardiothoracic Surgery, Thoraxcentrum Twente, Enschede, Netherlands
}

\begin{abstract}
The operative goals of the repair of postinfarction left ventricular aneurysms are to correct the size and geometry of the left ventricle in order to reduce wall tension and paradoxical movement and to improve the systolic function. Endoventriculoplasty has become the gold standard, since the late 1980s when it was described by Jatene and modified by Dor et al. Endoventriculoplasty using autologous endocardium for left ventricular aneurysm was first described by Grandjean et al. We present here a case report of on-pump beating heart endoventriculoplasty using autologous endocardium for postinfarction left ventricular anterior aneurysm. This technique, as a modification of the Dor technique, restores the ventricular geometry without leaving any segment of non-contractile ventricular wall and avoids the usage of prosthetic materials.
\end{abstract}

Key Words: Left ventricular aneurysm, endoventriculoplasty, myocardial infarction complications

\section{Introduction}

Myocardial infarction may be complicated by the formation of a left ventricular aneurysm that distorts the normal elliptical geometry of the ventricle to produce a dilated spherical ventricle with limited contractile and filling capacities (1). The operative goals of the repair of postinfarction left ventricular aneurysms are to correct the size and geometry of the left ventricle in order to reduce wall tension and paradoxical movement and to improve the systolic function and prevent thrombus formation, embolization and fatal ventricular tachyarrhythmias (2). Endoventriculoplasty has become the gold standard since the late 1980s, when it was described by Jatene and modified by Dor et al. (3, 4). Endoventriculoplasty, using autologous endocardium for left ventricular aneurysm, was first described by Grandjean et al. (5). We present here a case report of on-pump beating heart endoventriculoplasty using autologous endocardium for post-infarction left ventricular anterior aneurysm.

\section{Case Report}

A 56-year-old man with a history of myocardial infarction and transient ischemic attack 8 months earlier was admitted to our hospital. Electrocardiogram revealed $Q$ waves in leads V1-V4 with no ventricular arrhythmias. Transthoracic echocardiography showed apical dyskinesis, anterobasal, anterolateral and septal akinesis and a large apical aneurysm with a thrombus. Left ventricular ejection fraction (LVEF) was $30 \%$.
Cardiac catheterization and coronary angiography were performed which revealed $100 \%$ stenosis in the mid left anterior descending coronary artery (LAD) and a $70 \%$ stenosis in left posterolateral branch (LPL) of the circumflex artery and a large, true dyskinetic aneurysm with a mural thrombus in the apical segment of the left ventricular wall. The patient was scheduled for endoventriculoplasty and coronary artery bypass grafting. After median sternotomy, the left internal mammary artery (LIMA) was harvested with its pedicle. Cardiopulmonary bypass was established via cannulation of the ascending aorta and the right atrium with a two-stage cannula. The left ventricle was vented using a catheter inserted through the right superior pulmonary vein. The operation was performed on the beating heart during normothermic cardiopulmonary bypass. After a careful evaluation of the aneurysm, the left ventricle was opened in the middle of the aneurysm parallel to the septum. The mural thrombus was removed (Figure 1). The aneurysmatic wall was split into endocardial and epicardial layers up to the normal myocardial tissue using a dissecting scissor (Figure 2). The non-contractile parts of the endocardial layer were removed in a semicircular fashion in order to reduce the left ventricular volume and to restore the geometry of the ventricle (Figure 3). The endocardial and the epicardial layers were closed separately using double running sutures of 2-0 polypropylene (Figure 4). LAD was not graftable and LIMA was anastomosed to the LPL branch of the circumflex artery. The postoperative period was uneventful. The patient was in sinus rhythm with no arrhythmias. A postoperative transthoracic echocardiogram revealed a systolic left 


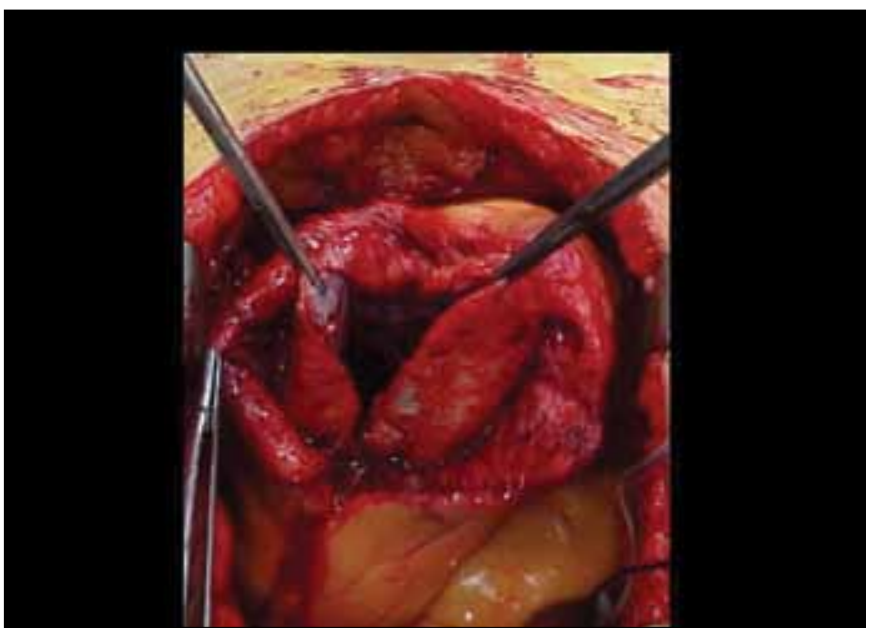

Figure 1. The aneurysmatic wall was split into endocardial and epicardial layers up to the normal myocardial tissue

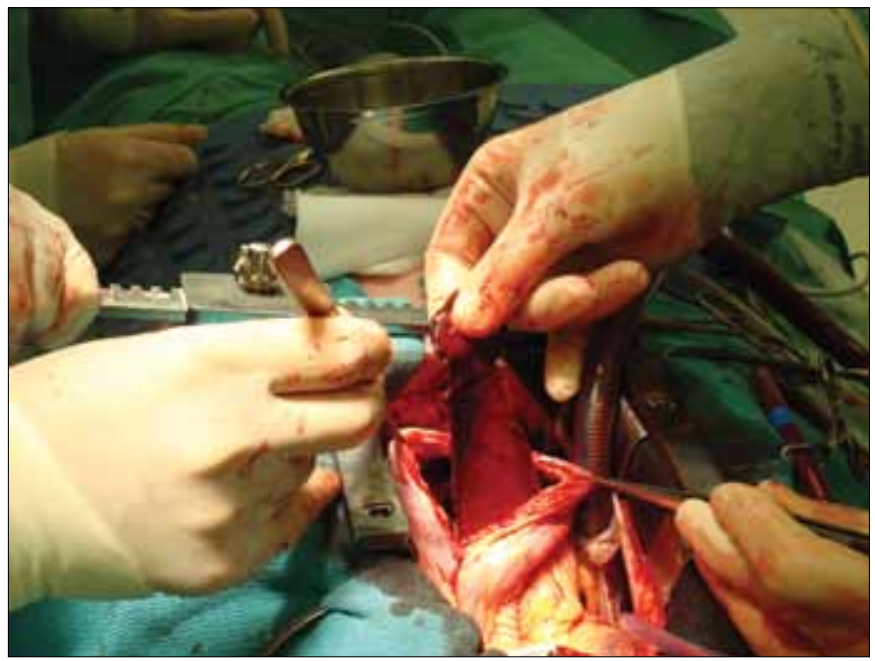

Figure 2. Apical mural thrombus removed

ventricular diameter of $25 \mathrm{~mm}$, a diastolic diameter of $49 \mathrm{~mm}$, a systolic left ventricular volume of $54 \mathrm{ml}$, a diastolic volume of $99 \mathrm{ml}$ and a LVEF of $45 \%$. The patient was discharged from hospital 6 days after the operation without any complication and continues to do well with an improved clinical condition after 18 months of follow-up.

\section{Discussion}

Several surgical techniques were developed for the repair of left ventricular aneurysms in order to regain normal left ventricular geometry and exclude non-contractile areas of the left ventricle $(1,6)$. Endoventriculoplasty, described as an alternative approach to linear repair technique, has gained wide popularity and has become the treatment of choice for anterior left ventricular aneurysms. Despite the anatomical and theoretical physiological advantages of the endoventriculoplasty techniques, one problem remains unsolved: which is the most efficient technique for the correction of postinfarction LV aneurysms? (7). Di Mattia et al. have suggested that a postoperative symmetrical contraction pattern

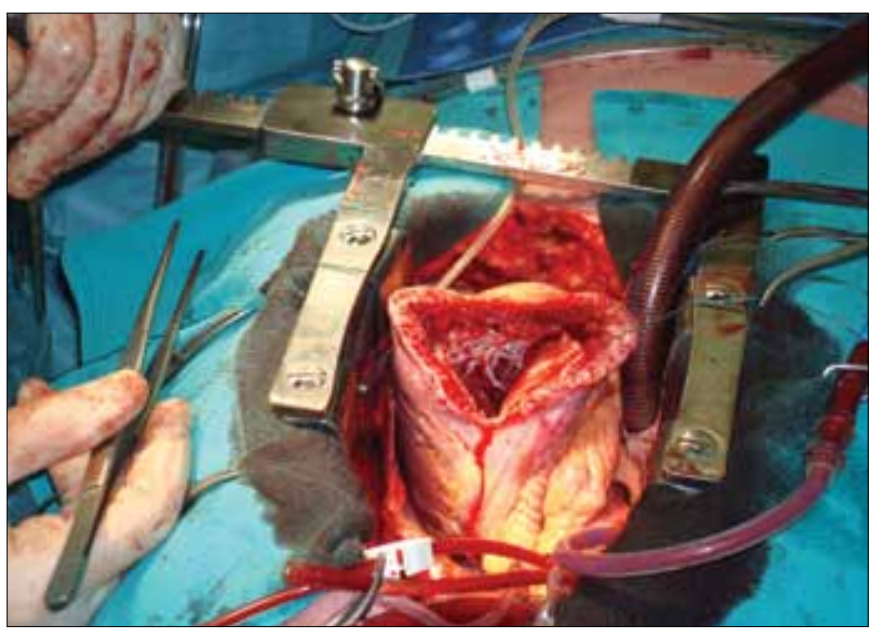

Figure 3. The non-contractile parts of the endocardial layer were removed in a semicircular fashion

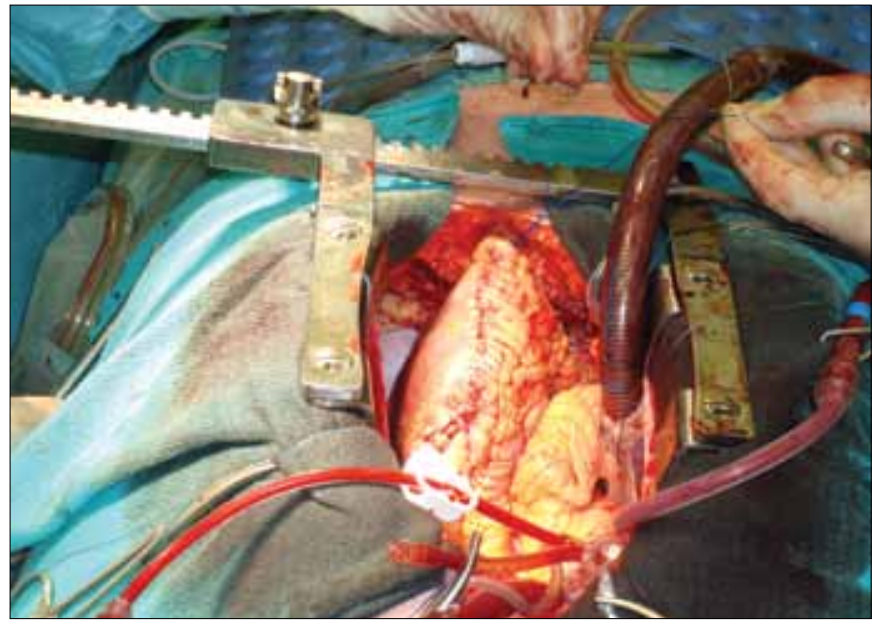

Figure 4. The endocardial and epicardial layers were closed separately using double running sutures of 2-0 polypropylene

is prognostic for a better hemodynamic trend in the long-term follow-up (8). Endoventriculoplasty using autologous endocardium, as a modification of the Dor technique, restores the ventricular geometry without leaving any segment of noncontractile ventricular wall and avoids the usage of prosthetic materials. It is very important to cut the rims of the endocardium in a semi-circular fashion in order to reconstruct the ventricular geometry. Performing this technique on the beating heart during cardiopulmonary bypass enables the surgeon to identify the conractile and non-contractile borders of the ventricular wall. Aortic insufficiency may necessitate the use of cardioplegic arrest during this part of the procedure (5).

Ventricular arrhythmia in the history of patients with left ventricular aneurysm indicates reduced long-term survival (9). Ventricular arrhythmia arises in the border zone between viable and dead myocardium. Endoventriculoplasty techniques might reduce wall tension on the septal border zone, and it is hypothesized that this might have an inherent antiarrhythmic effect (10). However, this is not supported in other clinical studies, and no experimental data exist. For patients with ventricular tachy-arrhythmias, surgical ablation combined 
with aneurysm repair and myocardial revascularization may be a possible curative procedure (11). Among several surgical procedures, two major approaches have become prevalent; ablation or resection of arrhythmogenic foci after precise localization by intraoperative mapping and extensive ablation procedures without mapping (12-15). We have not used perioperative mapping for this patient, since he had no ventricular arrhythmias preoperatively.

Endoventriculoplasty using autologous endocardium seems to overcome the problems related to other techniques in avoiding residual non-contractile tissue and restoring the physiological geometry of the left ventricle. Further studies with larger numbers of patients and long-term follow-up data are required in order to assess the effectiveness and safety of this technique.

\section{Conflict of Interest}

No conflict of interest was declared by the authors.

\section{References}

1. Antunes MJ, Antunes PE. Left ventricular aneurysms: from disease to repair. Expert Rev Cardiovasc Ther 2005;3:285-94. [CrossRef]

2. Yu Y, Gu CX, Wei H, Liu R, Chen CC, Fang Y. Repair of left ventricular aneurysm during off-pump coronary artery bypass surgery. Chin Med J (Engl) 2005;118:1072-5.

3. Jatene AD. Left ventricular aneurysmectomy: resection or reconstruction. J Thorac Cardiovasc Surg 1985;89:321-31.

4. Dor V, Saab M, Coste P, Komaszewska M, Montiglio F. Left ventricular aneurysm: a new surgical approach. Thorac Cardiovasc Surg 1989;37:11-9. [CrossRef]

5. Grandjean JG, Mariani MA, D'Alfonso A, Musazzi A, Boonstra PW. Endoventriculoplasty using autologous endocardium for anterior left ventricular aneurysms. Thorac Cardiovasc Surg 2005;53:52-5. [CrossRef]
6. Raja SG, Salehi S, Bahrami TT. Impact of technique of left ventricular aneurysm repair on clinical outcomes: current best available evidence. J Card Surg 2009;24:319-24. [CrossRef]

7. Marchenko AV, Cherniavsky AM, Volokitina TL, Alsov SA, Karaskov AM. Left ventricular dimension and shape after postinfarction aneurysm repair. Eur J Cardiothorac Surg 2005;27:475-80. [CrossRef]

8. Di Mattia DG, Di Biasi P, Salati M, Mangini A, Fundaro P, Santoli C. Surgical treatment of left ventricular post-infarction aneurysm with endoventriculoplasty: late clinical and functional results. Eur J Cardiothorac Surg 1999;15:413-8. [CrossRef]

9. Vural KM, Sener E, Ozatik MA, Tasdemir O, Bayazit K. Left ventricular aneurysm repair: an assessment of surgical treatment modalities. Eur J Cardiothorac Surg 1998;13:49-56. [CrossRef]

10. Sinatra R, Macrina F, Braccio M, Melina G, Luzi G, Ruvolo G, et al. Left ventricular aneurysmectomy; comparison between two techniques; early and late results. Eur J Cardiothorac Surg 1997;12:291-7. [CrossRef]

11. Frapier JM, Hubaut JJ, Pasquie JL, Chaptal PA. Large encircling cryoablation without mapping for ventricular tachycardia after anterior myocardial infarction: long-term outcome. J Thorac Cardiovasc Surg 1998;116:578-83. [CrossRef]

12. Bakker PFA, De Lange F, Hauer RNW, Derksen R, De Bakker JM. Sequential map-guided endocardial resection for ventricular tachycardia improves outcome. Eur J Cardiothorac Surg 2001;19:448-54. [CrossRef]

13. Nath $\mathrm{S}$, Haines DE, Kron IL, DiMarco JP. The long-term outcome of visually directed subendocardial resection in patients without inducible or mappable ventricular tachycardia at the time of surgery. J Cardiovasc Electrophysiol 1994;5:399-407. [CrossRef]

14. Dor V, Sabatier M, Montiglio F, Rossi P, Toso A, Di Donato M. Results of nonguided endocardiectomy associated with left ventricular reconstruction in patients with ischemic ventricular arrhythmias. J Thorac Cardiovasc Surg 1994;107:1301-8.

15. Wellens F, Geelen P, Demirsoy E, Van Praet F, De Geest R, Degrieck $I$, et al. Surgical treatment of tachyarrhythmias due to postinfarction left ventricular aneurysm with endoaneurysmorrhaphy and cryoablation. Eur J Cardiothorac Surg 2002;22:771-6. [CrossRef] 